\title{
POLYCYTHAEMIA VERA AND CHRISTMAS DISEASE WITH SLIGHTLY PROLONGED PROTHROMBIN TIME
}

\author{
BY \\ J. A. S. AMOS* \\ From the Royal South Hants Hospital, Southampton
}

(RECEIVED FOR PUBlication AUgust 10, 1959)

\begin{abstract}
A family is reported in which Christmas disease in one member and polycythaemia in another were associated with prolongations of the one-stage prothrombin time of the factor-VII deficiency type.

Changes in the prothrombin time were present in the siblings of the case of Christmas disease and in a number of unrelated cases of polycythaemia vera.

The use of " mixing procedures" did not reveal any significant mutual correction of the changes in prothrombin time.
\end{abstract}

de Vries, Kettenborg, and van der Pol (1955) described patients in whom serious abnormalities of blood coagulation were associated with slightly prolonged " one-stage" prothrombin times. They state that "generally not sufficient attention has been or is being paid to an apparently slight prolonging of the one-stage prothrombin time in clinical laboratories." Since then, a number of examples of combined clotting abnormalities of this type have been reported. In the cases of Bell and Alton (1955), Stein and Abrahams (1956), and Nour-Eldin and Wilkinson (1959), the serious coagulation abnormality is Christmas disease, while Constandoulakis (1958) describes a family showing true haemophilia also associated with prolonged prothrombin times in some of the members.

In these cases the prolonged prothrombin times have been due to a change in the patients' sera of the "factor-VII deficiency" pattern; the addition of $10 \%$ of normal serum rich in factor VII to the patients' plasma restores the prothrombin times to normal ; the patients' sera are not so effective as normal sera and plasma in correcting the prolonged prothrombin times of plasmas from patients receiving anticoagulant drugs of the dicoumarol type. Prolongations of the "one-stage" times due to deficiency in factor $\mathrm{V}$ and in prothrombin itself have been excluded by the appropriate tests. In these studies, a similar prolongation of the prothrombin time has been noted as an isolated change in the blood of the clinically unaffected relatives of patients *Present address: Department of Pathology, Redhill County Hospital, Surrey. with severe bleeding tendencies, some of the latter showing the combined defect. The changes are usually slight, the prothrombin times exceeding those of normal control plasmas by only a few seconds. It appears that the alterations in factorVII activity are an associated inherited change.

Patients with polycythaemia vera frequently have an increased tendency to bruise or bleed; however, the various blood coagulation investigations often give normal results and there are no constant changes. Björkman (1948) found decreased amounts of fibrinogen in the blood of patients with polycythaemia. In addition, his Case 1 showed a prolonged prothrombin time.

The purpose of the present paper is to describe the findings in a family in whom Christmas disease in one member and polycythaemia vera in another were associated with minor prolongations of the prothrombin time. The occurrence of differing blood dyscrasias within this family prompted study of unrelated cases of polycythaemia vera and allied disorders.

\section{Family History}

The family tree as far as can be traced is shown in Fig. 1, the tendency to bleeding affecting only male members and showing sex-linked inheritance.

\section{The S Family}

Charles S. died aged 68. He had always bruised easily and had had occasional nose bleeds. When aged 65 he had an operation for perforated peptic ulcer. In December, 1957, he began to lose strength and complain of giddiness. The spleen was not 


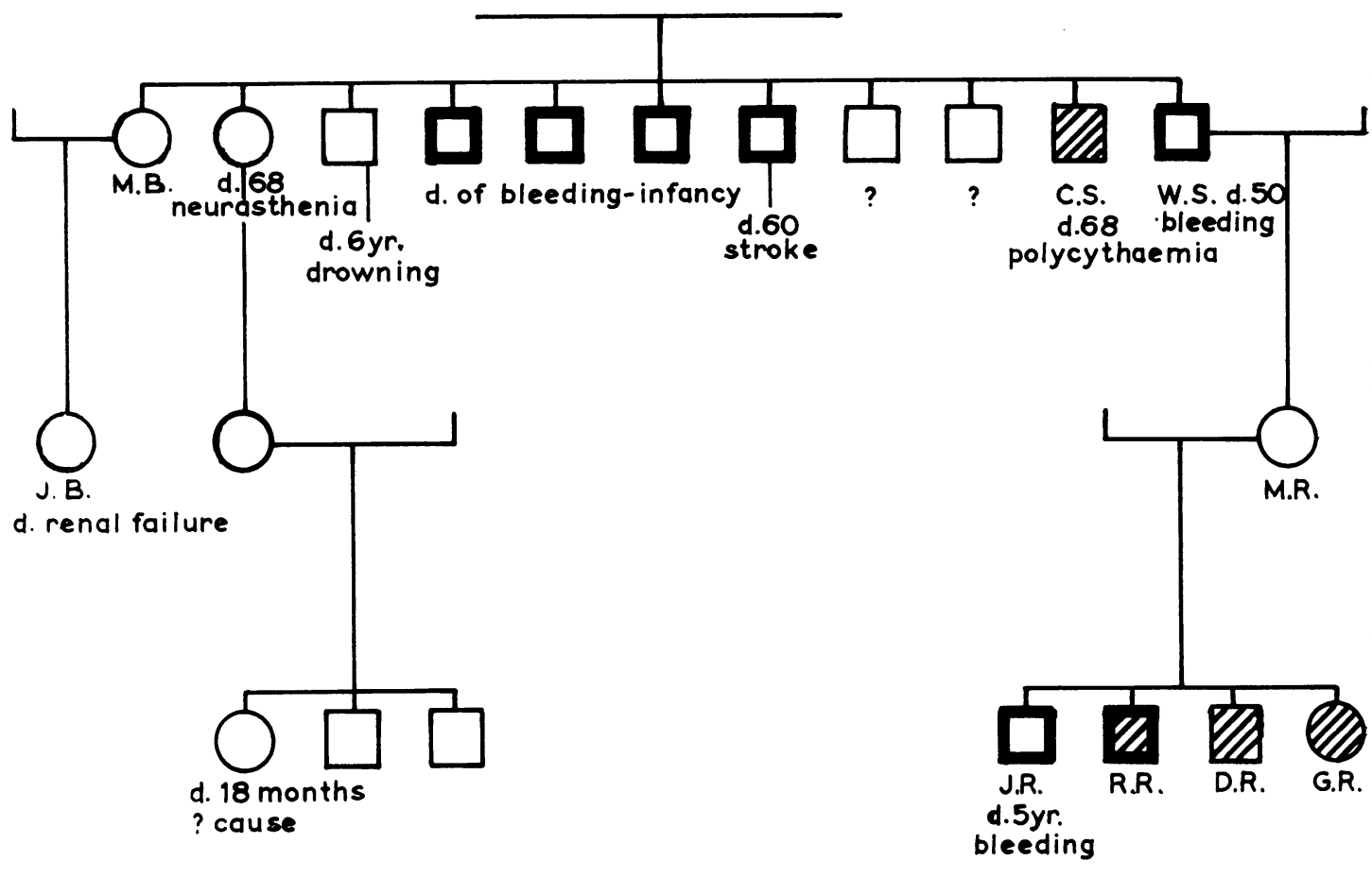

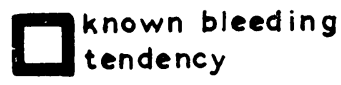

tendency


known factor VII deficient pattern

FIG. 1.-Pedigree of $\mathbf{R}$ and $\mathbf{S}$ families. palpable at this time, but the facies suggested polycythaemia vera. Blood examinations supported the diagnosis of polycythaemia and showed: haemoglobin $121 \%$ (17.9 g. per 100 ml.), R.B.C. 8,330,000 per c.mm., W.B.C. 22,400 per c.mm., P.C.V. 85, E.S.R. $1 \mathrm{~mm}$. in the first hour (Westergren), platelets 643,000 per c.mm. Liver function tests were normal. The Wassermann reaction and P.P.R. were negative. Hess's test was negative.

A sudden rectal haemorrhage led to his treatment in hospital for three weeks, the haemoglobin being $93 \%$ (13.8 g. per $100 \mathrm{ml}$.) and the P.C.V. 56 on discharge. He was then given radioactive phosphorus and remained well for three months, when he had a transient episode of auricular fibrillation. In September, 1958, he developed bronchitis and became disorientated, dying soon afterwards of a cerebrovascular accident.

Inquiry into the family history had shown that three brothers died of bleeding in infancy, while another brother suffered from bleeding episodes throughout life. Yet another brother, W.S., also a " bleeder," had severe haemarthroses and died aged 50 of internal bleeding. His daughter M.R. has had four children.

\section{The R Family}

M.R. shows no bleeding tendency and is in goodô health. John R. died aged 5 years of intra-abdominaß bleeding following a fall. He had bled frequentlyo since birth and severe haemarthroses had necessitated knee calipers.

Derek R. (aged 4) and Gillian R. (aged 18 months) are alive and well; neither have shown any bleeding symptoms or joint disorders.

Raymond $R$. is aged 9 years and has had severa severe episodes of bleeding necessitating six bloodw transfusions. Bleeding has followed minor injury o으 dental extraction. He has moderately severe kne haemarthroses.

\section{Laboratory Investigations}

Material and Methods.-Blood was collected byo clean venipuncture into one-ninth of its volume of $3.8^{\circ}$, trisodium citrate and the plasma separatec without delay by centrifugation for 20 to 30 minutes Serum was obtained from blood allowed to clot in plain glass containers and incubated at $37^{\circ} \mathrm{C}$. for two to four hours. Siliconed syringes and vesselor were used in the collection of many of the plasmat. 
specimens. Tests were carried out using standard laboratory procedures as described by Biggs and Macfarlane (1957). Prothrombin times were carried out by Quick's (1935) method using acetonedehydrated brain thromboplastin. Triplicate readings were taken and the results expressed as to the nearest half-second. Blood fibrinogen was measured by the biuret method following precipitation by thrombin (normal range 200 to $400 \mathrm{mg}$ \%).

Investigations were possible on M.B. and C.S. of the S family, and M.R., R.R., G.R., and D.R. of the $\mathbf{R}$ family. The relevant findings are shown in Tables I and II. M.R. and M.B. show no abnormality of blood coagulation. The bleeding times are within normal limits in all members. R.R. has shown an abnormal clotting time on several occasions. In C.S., D.R., G.R., and R.R. the one-stage prothrombin time is slightly prolonged. The change is "corrected" by the addition of normal stored serum. The qualitative tests for factor- $V$ deficiency and the two-stage prothrombin time (Biggs and Macfarlane, 1957) show no evidence of deficiency in factor $\mathrm{V}$ or in

TABLE I

RESULTS OF ROUTINE COAGULATION STUDIES OF

\begin{tabular}{|c|c|c|c|c|c|}
\hline & C.S. & M.R. & D.R. & G.R. & R.R. \\
\hline 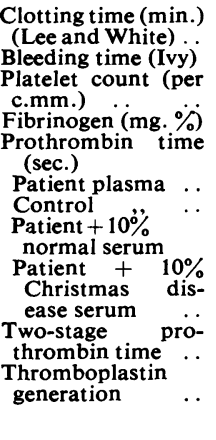 & $\begin{array}{c}15 \\
12 \\
11 \cdot 5 \\
12 \\
\text { Normal } \\
\text { Normal }\end{array}$ & $\begin{array}{c}13 \\
\text { Normal } \\
200,000 \\
340\end{array}$ & $\begin{array}{c}14 \\
12 \\
12 \\
12 \\
\text { Normal } \\
\text { Normal }\end{array}$ & $\begin{array}{c}6 \\
\text { Normal } \\
333,000 \\
320\end{array}$ & $\begin{array}{c}13 \\
\text { Normal } \\
\begin{array}{c}\text { Abnor- } \\
\text { mal }\end{array}\end{array}$ \\
\hline
\end{tabular}

TABLE II

THROMBOPLASTIN GENERATION IN PATIENT R.R. (USING NORMAL PLATELETS)

\begin{tabular}{|c|c|c|c|c|c|c|}
\hline Incubation time (min.): & 1 & 2 & 3 & 4 & 5 & 6 \\
\hline Incubation Mixture & \multicolumn{6}{|c|}{ Prothrombin Time (sec.) } \\
\hline $\left.\begin{array}{c}\text { Normal plasma } \\
,, \quad \text { serum }\end{array}\right\}$ & 38 & 22 & 15 & 12 & 11 & 11 \\
\hline $\begin{array}{l}\text { Patient's plasma } \\
\text { Normal serum }\end{array}$ & 32 & 16 & 12 & 11 & 10 & 10 \\
\hline $\left.\begin{array}{l}\text { Patient's serum } \\
\text { Normal plasma } \\
\text { Patient's serum }+\end{array}\right\}$. & 39 & 26 & 24 & 20 & 19 & 20 \\
\hline 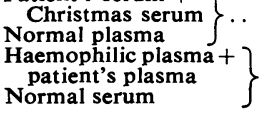 & 36 & 27 & 24 & 23 & 22 & 21 \\
\hline
\end{tabular}

the activity of prothrombin. The sera were less effective than normal stored sera in correcting the prolonged prothrombin times of plasma from patients receiving the anticoagulant drug phenindione ("dindevan" plasma). Serum from a case of Christmas disease* was as effective as normal serum in correcting the prolonged prothrombin times. The change appeared to be due to an alteration in the "factor-VII activity" of the sera.

Thromboplastin generation is abnormal in R.R. The results indicate that the defect is present in his serum, that admixture of his plasma with the plasma of a patient with true haemophilia produced normal thromboplastin generation, and that tests using the patient's serum and serum from a case of Christmas disease showed no mutual correction of the defects. It was concluded that the serious clotting abnormality in R.R. is Christmas disease, and that an associated change in "factor-VII" activity is also present in this boy, his brother and sister, and in Charles S.

\section{Further Investigations}

In view of the finding of a slightly prolonged prothrombin time in Charles S., it was decided to study unrelated patients with polycythaemia vera. The prothrombin times, tests of liver function, and fibrinogen estimations were carried out in 10 patients with polycythaemia vera, two patients with erythroleukaemia (P.M. and E.H.), and one patient with chronic marrow failure following polycythaemia (E.S.). The prothrombin times were measured without making any special allowance for variations in the concentration of anticoagulant in their plasma. Many of the patients were under treatment at the time of testing and their packed cell volumes were not markedly increased. The results are shown in Table III. Abnormalities of liver function were noted in seven patients. The zinc turbidity tests were within normal range in all subjects and are not included in the table; the thymol turbidity or flocculation tests, however, were abnormal in several patients. Blood fibrinogen estimations in 12 patients did not show any significantly reduced values.

The one-stage prothrombin times were slightly but definitely prolonged in several patients, and in J.W., J.S., E.H., P.M., and E.S. the blood changes showed the features of "factor-VII" deficiency, as far as was indicated by the addition of $10 \%$ normal serum and by the effect of the serum or plasma on the prolonged prothrombin time of 
TABLE III

LABORATORY FINDINGS IN 13 CASES OF POLYCYTHAEMIA VERA AND ALLIED DISORDERS

\begin{tabular}{|c|c|c|c|c|c|c|c|c|c|c|}
\hline \multirow{2}{*}{ Patient } & \multirow{2}{*}{\multicolumn{2}{|c|}{$\begin{array}{l}\text { Sex and } \\
\text { Age }\end{array}$}} & \multirow{2}{*}{ P.C.V. } & \multicolumn{2}{|c|}{$\begin{array}{l}\text { Prothrombin Time } \\
\text { to Nearest Second }\end{array}$} & \multicolumn{4}{|c|}{ Liver Function Tests } & \multirow{2}{*}{$\begin{array}{l}\text { Fibrinoger } \\
\text { (mg. } \%)\end{array}$} \\
\hline & & & & $\begin{array}{l}\text { Patient's } \\
\text { Plasma }\end{array}$ & $\begin{array}{l}\text { Control } \\
\text { Plasma }\end{array}$ & $\begin{array}{l}\text { Bilirubin } \\
\text { (mg. \%) }\end{array}$ & $\begin{array}{c}\text { Alkaline } \\
\text { Phosphatase } \\
\text { (K.-A. units) }\end{array}$ & $\begin{array}{l}\text { Thymol } \\
\text { Turbidity } \\
\text { (units) }\end{array}$ & $\begin{array}{c}\text { Thymol } \\
\text { Flocculation }\end{array}$ & \\
\hline $\begin{array}{l}\text { F.W. } \\
\text { C.H. } \\
\text { E.M. } \\
\text { C.K. } \\
\text { I.S. } \\
\text { F.T. } \\
\text { J.S. } \\
\text { J.S.K. } \\
\text { P.M. } \\
\text { E.S. } \\
\text { J.P. } \\
\text { E.H. } \\
\text { J.W. }\end{array}$ & $\begin{array}{l}\mathbf{M} \\
\mathbf{M} \\
\mathbf{F} \\
\mathbf{M} \\
\mathbf{F} \\
\mathbf{M} \\
\mathbf{F} \\
\mathbf{M} \\
\mathbf{F} \\
\mathbf{F} \\
\mathbf{M} \\
\mathbf{F} \\
\mathbf{F}\end{array}$ & $\begin{array}{l}57 \\
60 \\
79 \\
46 \\
60 \\
58 \\
54 \\
65 \\
47 \\
75 \\
52 \\
78 \\
75\end{array}$ & $\begin{array}{l}32 \\
52 \\
39 \\
36 \\
44 \\
66 \\
61 \\
51 \\
48 \\
51 \\
74 \\
53 \\
53\end{array}$ & $\begin{array}{l}16 \\
16 \\
15 \\
18 \\
13 \\
14 \\
13 \\
21 \\
15 \\
17 \\
16 \\
16 \\
16\end{array}$ & $\begin{array}{l}13 \\
12 \\
13 \\
13 \\
13 \\
12 \\
13 \\
14 \\
13 \\
13 \\
13 \\
13 \\
12\end{array}$ & $\begin{array}{r}0.5 \\
0.7 \\
0.7 \\
0.7 \\
0.5 \\
1.1 \\
0.6 \\
1.1 \\
<0.5 \\
0.6 \\
<0.5 \\
<0.5 \\
<0.5\end{array}$ & $\begin{array}{r}8 \cdot 3 \\
36 \cdot 4 \\
11 \cdot 8 \\
27 \cdot 2 \\
8 \cdot 3 \\
20 \cdot 6 \\
7 \cdot 2 \\
5 \cdot 8 \\
10 \cdot 8 \\
10 \cdot 8 \\
12 \\
9 \cdot 5 \\
9 \cdot 5\end{array}$ & $\begin{array}{l}3 \\
3 \\
1 \\
2 \\
1 \\
2 \\
6 \\
3 \\
4 \\
1 \\
5 \\
5 \\
3\end{array}$ & $\begin{array}{l}\text { Negative } \\
\text { Negative } \\
\text { Negative } \\
\text { Positive } \\
\text { Negative } \\
\text { Negative } \\
\text { Positive } \\
\text { Negative } \\
\text { Positive } \\
\text { Negative } \\
\text { Negative } \\
\text { Positive } \\
\text { Negative }\end{array}$ & $\begin{array}{l}220 \\
360 \\
250 \\
230 \\
210 \\
200 \\
270 \\
-220 \\
370 \\
400 \\
430 \\
250\end{array}$ \\
\hline
\end{tabular}

"dindevan" plasma. Aluminium hydroxideadsorbed normal plasma was ineffective in "correcting" the prothrombin times and the twostage prothrombin times were normal.

The one-stage prothrombin time in E.S. was 17 seconds and in P.M. 15 seconds (control times 13 seconds) before and 24 hours after giving intramuscular vitamin $\mathbf{K}_{1}$.

Mixtures of sera and plasma were tested to see whether any mutual correction occurred; such mixing procedures were carried out between the various members of the $R$ and $S$ families, between members of the family and unrelated polycythaemics, and between the polycythaemics themselves. In some cases, the prothrombin times for mixtures of plasma were measured directly; aluminium hydroxide-adsorbed normal plasma was added to the incubating mixtures as a source of factor $V$. In other tests, use was made of the ability of sera or plasmas or of mixtures to shorten the prolonged prothrombin times of "dindevan" plasma. Representative findings are shown in Tables IV and V. It was found that

\section{TABLE IV}

PROTHROMBIN TIMES OF TEST PLASMAS AND MIXTURES OF TEST PLASMAS

\begin{tabular}{|c|c|c|c|c|c|c|c|}
\hline \multirow[b]{3}{*}{$\underset{19}{\text { Normal }}$} & \multicolumn{7}{|c|}{ Prothrombin Time (sec.) } \\
\hline & \multicolumn{7}{|c|}{ Source of Plasma (2 vol.) } \\
\hline & $\begin{array}{l}\text { C.S.S. } \\
22 \cdot 5\end{array}$ & $\underset{22}{\text { R.R. }}$ & $\underset{23}{\text { D.R. }}$ & $\underset{26}{\text { J.P. }}$ & E.H. & $\underset{23}{\text { J.W. }}$ & E.S. \\
\hline & \multicolumn{7}{|c|}{ Source of Plasma (1 vol.) } \\
\hline $\begin{array}{l}\text { Source of } \\
\text { plasma } \\
\text { (1 vol.) }\end{array}$ & $\begin{array}{c}\text { R.R. } \\
\text { C.S. } \\
\text { D.R. } \\
\text { Normal }\end{array}$ & $\begin{array}{l}\text { C.S. } \\
\frac{22}{19}\end{array}$ & $\begin{array}{c}\text { D.R. } \\
24 \\
24 \\
\frac{19}{19}\end{array}$ & $\begin{array}{l}\text { J.P. } \\
25 \\
26 \\
22 \\
19\end{array}$ & $\begin{array}{l}\text { E.H. } \\
27 \\
23 \\
21 \cdot 5 \\
19\end{array}$ & $\begin{array}{c}\text { J.W. } \\
24 \\
22 \\
23 \\
19\end{array}$ & $\begin{array}{l}\text { E.S. } \\
23 \\
23 \cdot 5 \\
23 \\
19\end{array}$ \\
\hline
\end{tabular}

The inc abated mixture consisted of 2 vol. of test plasma or mixture of equal volumes of test plasmas, and 1 vol. of aluminium-hydroxideadsorbed normal plasma.
TABLE V

EFFECT OF TEST SERA AND MIXTURES OF TEST SERA ON PROTHROMBIN TIMES OF DINDEVAN PLASMAS (TENTH DAY OF TREATMENT)

\begin{tabular}{|c|c|c|c|c|c|c|}
\hline \multirow[b]{3}{*}{$\begin{array}{c}\text { Dindevan plasma } A \\
(18 \text { vol. })\end{array}$} & \multicolumn{6}{|c|}{ Prothrombin Time (sec.) } \\
\hline & \multicolumn{6}{|c|}{ Source of Serum or Saline ( 2 vol.) } \\
\hline & $\begin{array}{l}\text { Normal } \\
\text { Saline } \\
\quad 36\end{array}$ & $\begin{array}{c}\text { Normal } \\
\text { Serum } \\
20\end{array}$ & $\begin{array}{l}\text { C.S. } \\
23 \cdot 5\end{array}$ & $\underset{28}{\text { R.R. }}$ & $\underset{29}{\text { G.R. }}$ & D.R. \\
\hline $\begin{array}{c}\text { Dindevan plasma B } \\
\text { (18 vol.) }\end{array}$ & $\begin{array}{c}\text { Normal } \\
\text { Saline } \\
44\end{array}$ & $\begin{array}{c}\text { Normal } \\
\text { Serum } \\
20\end{array}$ & $\begin{array}{l}\text { J.P. } \\
24 \cdot 5\end{array}$ & \multicolumn{2}{|c|}{ J.W. } & $\underset{23 \cdot 5}{\text { E.H. }}$ \\
\hline \multirow[b]{2}{*}{$\begin{array}{c}\text { Dindevan plasma } A \\
\text { (18 vol.) }\end{array}$} & \multirow{3}{*}{ 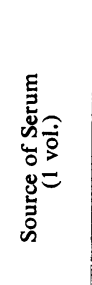 } & \multicolumn{5}{|c|}{ Source of Serum (1 vol.) } \\
\hline & & $\begin{array}{l}\text { R.R. } \\
\text { G.R. } \\
\text { D.R. }\end{array}$ & $\begin{array}{l}\text { C.S. } \\
26 \cdot 5 \\
25 \\
22 \cdot 5\end{array}$ & \multicolumn{2}{|c|}{$\begin{array}{l}\text { D.R. } \\
23 \cdot 5 \\
23 \\
-\end{array}$} & $\begin{array}{c}\text { G.R. } \\
29 \\
=\end{array}$ \\
\hline $\begin{array}{c}\text { Dindevan plasma B } \\
\text { (18 vol.) }\end{array}$ & & $\begin{array}{l}\text { C.S.S. } \\
\text { R.R. } \\
\text { D.R. } \\
\text { J.W. } \\
\text { E.H. }\end{array}$ & $\begin{array}{l}\text { J.P. } \\
24 \cdot 5 \\
25 \cdot 5 \\
23 \cdot 5 \\
23 \\
25\end{array}$ & $\begin{array}{l}26 \\
31 \\
22\end{array}$ & $\begin{array}{l}\text { W. } \\
-5 \\
-\end{array}$ & $\begin{array}{l}\text { E.H. } \\
23 \cdot 5 \\
25 \cdot 5 \\
22 \\
25 \\
-\end{array}$ \\
\hline
\end{tabular}

normal serum shortened the prothrombin times 을 of "dindevan" plasma to a greater extent than $\frac{}{0}$ sera and plasma of the various subjects or of mixtures of sera. Tests using mixtures of plasmas $N$ showed no significant mutual correction of the $N$ changes.

\section{Discussion}

Although polycythaemia vera is occasionallye familial (Nadler and Cohn, 1939) and Christmas $\bar{\perp}$ disease shows classical haemophilia-like sex- $\stackrel{?}{+}$ linked inheritance, the occurrence of these blood $\underline{T}$ dyscrasias within a family is probably coincidental. In reviewing familial leukaemia and other serious $\stackrel{\Phi}{\mathscr{\complement}}$ blood disorders, Guasch (1954) notes only $\underset{\complement}{\mathbb{Q}}$ occasional examples of the familial association of haemorrhagic states with other serious blood diseases. Instances of different blood disorders 
occurring within one family are generally too few for any specific associations to be apparent.

The slightly prolonged prothrombin times in the present family may be an inherited change in the factor-VII activity of the blood. The changes have been noted in the $R$ family in tests carried out on several separate occasions. The unaffected members of the families reported by Bell and Alton (1955) and Constandoulakis (1958) show similar variation in the one-stage prothrombin time. Although combined coagulation deficiencies are uncommon, a change in factor-VII activity has been most often noted in association with Christmas disease, itself of much lower incidence than classical haemophilia. The association may prove to be more frequent than can be accounted for by the chance association of separate inherited coagulation disorders. A further feature is that the changes in prothrombin time in these familial examples have been slight, and near the limits of normal variability. Ingram and Armitage (1959) have investigated the normal range of Quick's prothrombin time determinations and found the differences in prothrombin times of normal persons to be greater than can be accounted for by the experimental errors of the method. The causes of this variability and their possible relationship to minor changes of the factor-VII deficiency type are not yet fully explained.

The serum factors concerned in blood coagulation are complex, and their classification and interrelationships are uncertain. Apart from Christmas factor, several members with factor-VII-like activity have been distinguished; these include the Prower-Stuart factor (Telfer, Denson, and Wright, 1956), the factor deficient in cases of congenital factor-VII deficiency (Owren, 1952; Dische, 1958), and a further thromboplastin-forming substance, C (Biggs, 1956). These members of the complex have been intensively studied by using " mixing procedures": Bachmann, Duckert, Geiger, Baer, and Koller (1957) summarize the findings in 40 reported cases of factor-VII complex abnormalities; a number of cases remain unclassified and include those familial examples associated with Christmas disease. It is perhaps significant that these cases show only slight prolongations of the prothrombin time, contrasting with the grossly abnormal times of many of the other cases. Further work is necessary to clarify the relationships of these various members.

It is well recognized that minor prolongations of the prothrombin time, sometimes of the factorVII deficiency pattern, are found in patients with malabsorption states or severe liver disease. The significance of the finding in the present cases of polycythaemia vera is uncertain. In the five patients investigated, the prolonged prothrombin time appeared to be due to a change in factor-VII activity.

Abnormalities of liver function tests were noted in some of the patients. The biochemical findings and the inability of vitamin $K_{1}$ to alter the prothrombin time in two of the patients suggests that the changes in prothrombin time may be an index of hepatic dysfunction recognized to be a not infrequent feature of polycythaemia vera (Tinney, Hall, and Giffin, 1943). As far as is indicated by the mixing procedures employed, no significant differences were noted between the changes in factor-VII activity of the blood of the members of the family studied and those observed in the patients with polycythaemia vera, or related disorders.

I am deeply grateful to Dr. T. P. Lalonde and Dr. R. H. Walker for their help and encouragement in investigating their patients of the $\mathbf{R}$ and $\mathbf{S}$ families ; to Miss G. Penney for technical help, and to $\mathrm{Mr}$. F. Grimes for the biochemical estimations.

\section{REFERENCES}

Bachmann, F., Duckert, F., Geiger, M., Baer, P., and Koller, F. (1957). Thromb. Diath. Haem. Stuttg., 1, 169.

Bell, W. N., and Alton, H. G. (1955). Brit. med. J., 1, 330.

Biggs, R. (1956). Brit. J. Haemat., 2, 412.

and Macfarlane, R. G. (1957). Human Blood Coagulation and its Disorders, 2nd ed. Blackwell Scientific Publications, Oxford. Björkman, S. E. (1948). Acta. med. scand., 129, 472.

Constandoulakis, M. (1958). J. clin. Path., 11, 412.

Dische, F. E. (1958). Brit. J. Haemat., 4, 201.

Guasch, J. (1954). Sang, 25, 384.

Ingram, G. I. C., and Armitage, P. (1959). J. clin. Path., 12, 91.

Nour-Eldin, F., and Wilkinson, J. F. (1959). Lancet, 1, 1173.

Owren, P. A. (1952). New Clotting Factors. In Blood Clotting and Allied Problems: Trans. 5th Conf., 1952, p. 92. Josiah Macy, Jr., Foundation, New York.

Quick, A. J. (1935). J. biol. Chem., 109, lxxiii.

Stein, H. B., and Abrahams. O. L. (1956). S. Afr. J. med. Sci., 21, 13

Stein, H. B., and Abrahams. O. L. (1956). S. Afr. J. med. Sci., 21, 13.
Telfer, T. P., Denson, K. W., and Wright, D. R. (1956). Brit. J. Haemat., 2, 308.

Tinney, W. S., Hall, B. E., and Giffin, H. Z. (1943). Proc. Mayo Clin., 18, 46.

Vries, S. I. de, Kettenborg, H. K., and Pol, E. T. van der (1955). Acta haemat. (Basel), 14, 43. 